\title{
VERIFICATION TO THE RSG-GAS FUEL DISCHARGE BURN-UP USING SRAC2006 MODULE OF COREBN/HIST
}

\author{
J. Susilo $^{1}$, T.M. Sembiring ${ }^{1}$, M. Imron ${ }^{2}$, G.R. Sunaryo ${ }^{1}$ \\ ${ }^{1}$ Center for Nuclear Reactor Technology and Safety, BATAN \\ ${ }^{2}$ Center for Multipurpose Reactor G.A. Siwabessy, BATAN \\ Email: shushilo@,batan.go.id \\ Diterima editor: 9 Januari 2018 \\ Diperbaiki: 30 Januari 2018 \\ Disetujui untuk publikasi: 2 Februari 2018
}

\begin{abstract}
VERIFICATION TO THE RSG-GAS FUEL DISCHARGE BURN-UP USING SRAC2006 MODULE OF COREBN/HIST. For 30 years operation, some of the modifications to the RSG GAS core has been done, that are changes included the type of fuel from U3O8-Al to U3Si2-Al with the same density $2.96 \mathrm{gU} / \mathrm{cc}$, the loading pattern of standard fuel elements/fuel control elements from $6 / 1 \& 6 / 2$ to $5 / 1$ pattern, and in core fuel management calculation tool has been change from IAFUEL to BATANFUEL. To obtain an extension of the operating license for the next 10 years, the RSG-GAS Periodic Safety Assessment Document is need to prepared. According to the Regulatory Body Chairman Regulation No. 2 2015, RSG-GAS safety assessment should be done independently. As part of this assessment the fuel discharge burn-up must be estimated. In this research, to ensure that the misposition of fuel element in the core has not occurred, the investigation to the document operating report related the fuel placement has been done. Therefore, by using 78th to 93rd operation data, verify of the fuel discharge burn-up of the RSG-GAS has been performed by using SRAC2006 module of COREBN/HIST. In addition, the results of these calculations are also made comparative with the operating report data that is calculated by using BATAN-FUEL. Maximum fuel discharge burn-up (57.73\% of U-235) was verified still under permissible value determined by the regulatory body $(<60 \%$ of U-235). Maximum differences value between two computer codes was about $2.12 \%$ of U-235 $(3.80 \%)$ that is fuel at the B-7 position. Fuel discharge burn-up of RSG-GAS showed almost the same value for each the operation cycle, range of $1.52 \%$ of U-235. So it can be concluded that the RSG-GAS core operation over the last ten years was in good fuel management performance, in accordance with the design. BATAN-FUEL has been comformed well enough with COREBN/HIST.
\end{abstract}

Keywords: Discharge Burn-Up, RSG-GAS, COREBN/HIST, BATAN-FUEL

\begin{abstract}
ABSTRAK
VERIFIKASI TERHADAP BURN-UP BUANG BAHAN BAKAR TERAS RSG-GAS MENGGUNAKAN SRAC2006 MODUL COREBN/HIST. Selama 30 tahun beroperasi, RSG-GAS telah mengalami perubahan modifikasi antara lain jenis bahan bakar dari U3O8-Al menjadi U3Si2-Al dengan kerapatan sama 2,96 gU/cc, pola pemuatan bahan bakar standar/elemen kendali dari pola 6/1 \& 6/2 menjadi pola 5/1, dan alat perhitungan manajemen bahan bakar IAFUEL dengan BATAN-FUEL. Untuk memperoleh perpanjangan ijin operasi selama 10 tahun ke depan, maka perlu disiapkan dokumen Penilaian Keselamatan Berkala RSG-GAS. Berdasarkan PerKa BAPETEN No. 2 Tahun 2015, maka penilaian keselamatan RSG-GAS harus dilakukan secara independen. Salah satu parameter yang perlu diverifikasi adalah nilai bahan bakar buang. Dalam penelitian ini, dilakukan investigasi terhadap dokumen Laporan Operasi untuk memastikan bahwa tidak terjadi kesalahan penempatan bahan bakar. Selanjutnya, berdasarkan data siklus operasi teras ke 78 sampai dengan 93, dilakukan verifikasi nilai burn-up buang bahan bakar RSG-GAS dengan menggunakan SRAC2006 modul COREBN/HIST. Selain itu, hasil perhitungan tersebut juga dilakukan komparasi dengan data laporan operasi yaitu data hasil perhitungan menggunakan BATAN-FUEL. Fraksi bakar buang bahan bakar terbesar (57,73\% U-235) terverivikasi masih di bawah nilai limit yang ditetapkan oleh badan pengawas $(<60 \%$ U-235). Perbedaan hasil perhitungan terbesar kedua program computer sebesar 2,12\% U-235 (3,80\%) yaitu pada posisi B-7. Fluktuasi burn-up buang bahan bakar menunjukkan nilai yang hampir sama untuk tiap-tiap siklus operasi, jarak (range) sebesar 1,52\% U-235. Sehingga dapat disimpulkan bahwa operasi teras RSG-GAS selama sepuluh tahun terakhir menunjukkan performa manajemen bahan bakar yang baik, sesuai desain. BATAN-FUEL telah terkonfirmasi cukup baik dengan COREBN/HIST.
\end{abstract}

Kata kunci: Burn-up buang, RSG-GAS, COREBN/HIST, BATAN-FUEL

DOI: $\underline{10.17146 / \mathrm{tdm} .2018 .20 .1 .4041}$ 


\section{INTRODUCTION}

Indonesia has been successfully operating three research reactors, namely TRIGA 2000k reactor in Bandung, Kartini reactor in Yogyakarta, and Multipurpose Reactor G.A. Siwabessy (RSGGAS) in South Tangerang. RSG-GAS or called with Multi-Purpose Reactor 30 MW (MPR30), is a pool-type research reactor are utilized for radioisotope production, material test, neutron activation, and research activity. At a nominal power of $30.00 \mathrm{MWth}$, it produces a thermal neutron flux of about $2.00 \times 10^{14} \mathrm{n} / \mathrm{cm}^{2} / \mathrm{sec}$. RSG-GAS is designed to use low enrichment fuel (19.75\%). Since its first criticality, which was achieved on 29 July 1987, RSG GAS has been operating for 30 years, and now reached to the $94^{\text {th }}$ operating cycle. Some of the changes/modifications that have been made to the core design are the replacement of the fuel type from $\mathrm{U}_{3} \mathrm{O}_{8}-\mathrm{Al}$ to $\mathrm{U}_{3} \mathrm{Si}_{2}-\mathrm{Al}$ with the same density (2.96 grU/cc), and the standard fuel elements /control fuel element loading pattern from 6/1 \&6/2 patterns to be a $5 / 1$ pattern. RSG-GAS core with $5 / 1$ loading pattern has 40 standard fuel elements and 8 control elements with a total of 48 fuels. Since there are eight fuel burn-up classes, thus each fuel will be inside reactor core for 8 operating cycles. In addition, the fuel management tool has also been replaced from IAFUEL to BATAN-FUEL.

To obtain an extension of the operating license for the next 10 years, one of the documents that need to be prepared is the RSG-GAS Periodic Safety Assessment Document. To complete the contents of the document, an analysis of the RSG-GAS core safety parameter measurement results for the last 10 years has been performed and the result indicates that RSG-GAS operation has a good performance [1].

However, not all of the safety parameters can be determined by measurement. One example of the parameters that are important for neutronic safety to be assessed is the fuel discharge burnup. The discharge burn-up value shows the characteristics of fuel management in the core which include the placement position and the loading pattern of fuels used by a nuclear reactor. Characteristics of fuel management in the core will affect the value of neutronic parameters produced such as neutron flux, power peaking factor, and reactivity in the core.

During operation, inside the reactor core a fission reaction occurs between U-235 fuel and neutrons producing energy and fission results. The longer the fission reacts, the burn-up of fuel will be higher, and the amount of fission produced will also increase. Since the value of fuel burnup will influence the fuel integrity. Fuel that has discharge burnup exceeds the specified limits is likely to be damaged (swelling) caused by fission product gas accumulation which may eventually lead to release of radioactive substances in the primary cooling system. Therefore, the research on the fuel burn-up is very important to be done for not only to RSG-GAS core, but also another types of reactor, namely power reactor and another research reactor. Several studies related to the fuel burn-up, include

- Simulation of burnup calculation at power plant [2-5]

- Analysis to the fuel burnup of the MTR type research reactor [6, 7]

- Analysis of measurements data of the RSG-GAS research reactor [8-11]

In the RSG-GAS core in-core fuel management, calculations using computer programs are performed to determine the discharge burn-up in each operating cycle. The computer program as a calculation tool for RSG-GAS core fuel burn-up has been replaced with BATAN-FUEL, previously using the computer program of IAFUEL [12]. Computer program IAFUEL has been being used since the first cycle of operation in 1987, to conduct the in-core fuel management and to record the fuel elements history of RSG-GAS. BATAN-FUEL computer code was developed by BATAN to simulate the fuel burn-up of the core on the reactor model of 2 dimensional geometry X-Y. BATAN-FUEL has been validated well with the indicator value that is linear with the change of burn-up value. The value of indicator is obtained from measurement through nondestructive test system. In the calculation, as input data, the macroscopic cross-sectional data is generated through calculation using WIMSD/5 with ENDFB7 cross-section library. WIMSD/5 is a general code for reactor lattice cell calculation with 69 energy groups, based either the Carlson DSN method or by collision probability methods to solve the transport equation

According to the Regulatory Body Chairman Regulation No. 22015 about Verification and Assesment of The Non Power Reactor Safety, RSG-GAS safety assessment should be done independently. In this research, to ensure that the fuel discharge burn-up has not exceeded due to 
the misposition of the fuel elment in the core, the investigation of the operating report documents related to the fuel placement has been done for the operating cycle no. 78 to 93 . By using these operation data, the calculation for the fuel discharge burn-up of RSG-GAS has been performed in the modeling of three-dimensional geometry. The calculation has been done by using computer program SRAC2006 module of COREBN/HIST. The COREBN/HIST is a computer program based on finite difference diffusion and macroscopic cross-section interpolation for a multidimension core burn-up calculation. The macroscopic cross-sectional data of fuel elements calculated using PIJ module with JENDL3.3 cross-sectional data. Top and bottom of fuel materials macroscopic cross-section calculated by using ANISN module, and for another non-fuel materials calculated by using CITATION module. PIJ is a neutron transport calculation module that uses the neutron collision probability theory in solving Boltzman equations. In the PIJ module, 107 groups of energy neutrons are used. ANISN is computer program based on one-dimensional SN transport. CITATION is a multi dimensional diffusion code.

This study aims to verify that the value of discharge burn-up of fuel generated in each RSGGAS operating cycle does not exceed the specified limit. This can be known through calculations using COREBN/HIST. In addition, to know the level of conformity of the calculation results, then comparison of the calculation of the fuel burn-up between COREBN/HIST with BATAN-FUEL was conducted with the same core operating data.

\section{METHODOLOGY}

To determine the fuel discharge burn-up, the calculation of RSG-GAS fuel burn-up distribution in each cycle operation of the core has been done. The core calculation was performed in the 3-dimensional geometry by using the computer program SRAC2006 module of COREBN/HIST.

\section{Creating Input Data}

Input of program data calculation of SRAC2006 module of COREBN / HIST, among others, are geometry of the core, operating data, and macroscopic cross-sectional data of fuel and other materials. Each of the required input data is described as follows.

- Makroscopic crossection of Fuel and Non Fuel Material

The macroscopic cross-sectional data was obtained through calculations using the PIJ module through the following calculation steps.

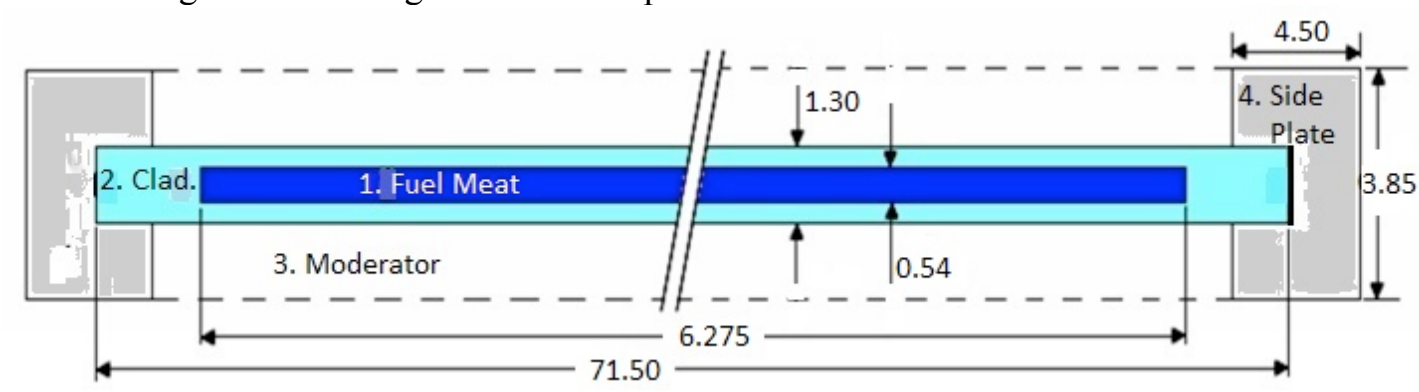

Figure 1. Fuel lattice cell model of RSG-GAS core (unit in $\mathrm{mm}$ )

The first step is to model the fuel cell lattice. As shown in Figure 1, the fuel cell lattice of the RSG-GAS is modeled into 2-dimensional geometry of rectanguler. The fuel cell lattice is composed of $\mathrm{U}_{3} \mathrm{Si}_{2}-\mathrm{Al}$ fuel meat, $\mathrm{AlMg}_{2}$ cladding, and $\mathrm{H}_{2} \mathrm{O}$ moderator as well as coolant with a thickness of $0.54 \mathrm{~mm}, 0.38 \mathrm{~mm}$ and $1.275 \mathrm{~mm}$, respectively. Both ends of the fuel plate are assembled with side plate of the fuel rack that has a thickness of about $3.85 \mathrm{~mm}$ in length and 4.50 $\mathrm{mm}$ in width.

The second step is to calculate the fuel cell lattice macroscopic cross-section function of burn-up. The calculation was done with PIJ module. 

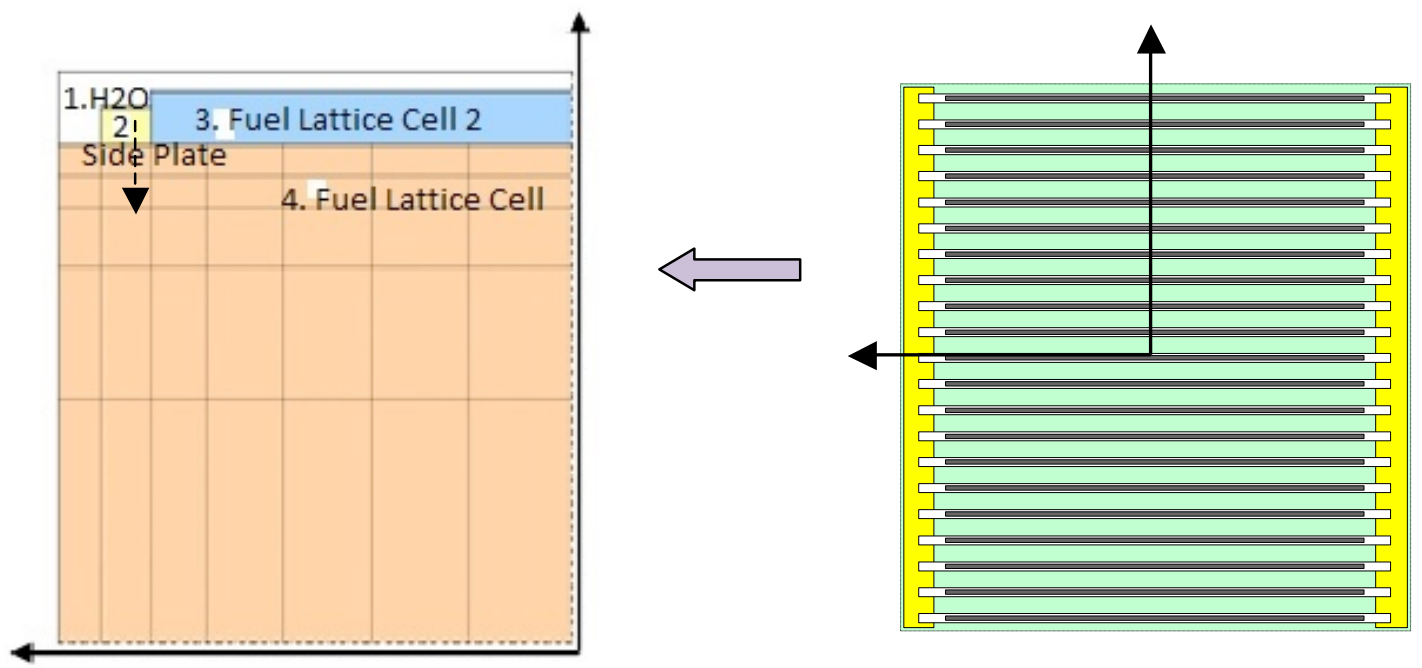

Standard fuel element model

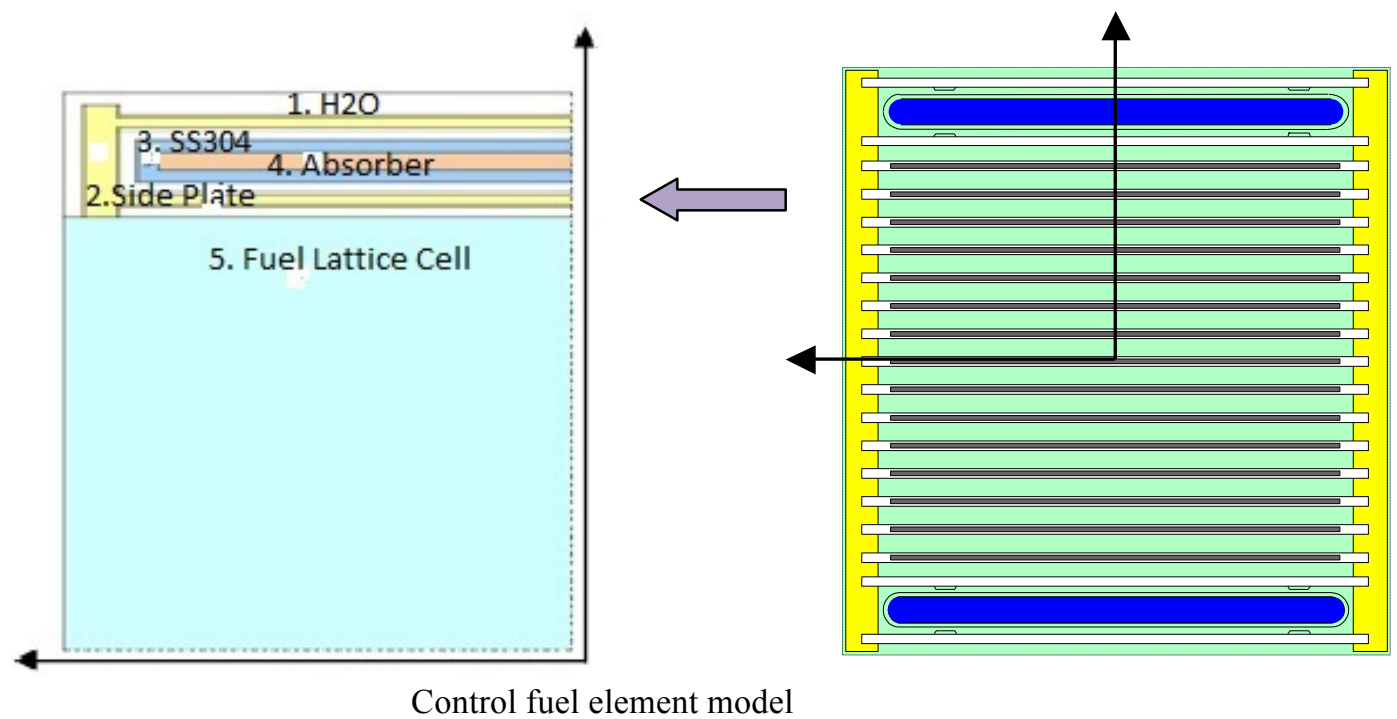

Figure 2. Standard fuel element and control fuel element model of RSG-GAS

The third step is to model standard fuel element and control fuel element. As shown in Figure 2, standard fuel element is composed of 21 fuel plates, side plate $\mathrm{AlMg}_{2}$, and moderator $\mathrm{H}_{2} \mathrm{O}$. Size length $\times$ width $\times$ height of standard fuel element and control fuel element (unit in $\mathrm{cm}$ ) are $7.71 \times 8.10$ $\times 60.00$. The standard fuel element modeled into 2 -dimensional geometry for a $1 / 4$ part. The model of standard fuel element is composed of moderators $\mathrm{H}_{2} \mathrm{O}$, side plate $\mathrm{AlMg}_{2}$, homogenization of the fuel lattice cell with side plate and homogenization of the fuel lattice cell without side plate. The control element, as shown in Figure 3, composed of 15 fuel plates, absorbent, $\mathrm{H}_{2} \mathrm{O}$ moderator, and fuel rack. The model of control fuel element was also done in 2-dimensional geometry of the $1 / 4$ part. The control element model is composed of moderator $\mathrm{H}_{2} \mathrm{O}$, side plate (rack of fuel), $\mathrm{SS} 304$ absorbent housing/cladding, AgInCd absorbent, and homogenization of fuel lattice cell.

The fourth step is to calculate macroscopic cross-section of the fuel elements and control fuel elements for each burn-up level on the fuel lattice cell. The calculation is also done with the PIJ module. In this calculation, neutron energy is condensed from 107 to 8 group.

The calculation of macroscopic cross-section for the nonfuel materials such as beryllium reflector block, beryllium element, HYRA, PNRS, PRTF and CIP / IP have been performed using CITATION module to the 2-dimensional of the first cycle of RSG-GAS core. While the nonfuel material at the top and bottom of fuel are calculated with ANISN module for 1-dimensional geometry of fuel. 
- RSG-GAS geometry data

Figure 3 shows the horizontal RSG-GAS terraces model (X-Y) and axial (Z). As shown in the Figure 3, the horizontal RSG-GAS core model is composed of $10 \times 10$ grids consisting of 40 fuel elements, 8 control elements, 4 CIPs, 4 IPs, 5 HYRS/PNRS, 2 PRTFs, and 37 Berrylium Elements. In addition, beyond the active core there is also a Berrylium block reflector. The size of one grid is $7.71 \mathrm{~cm} \times 8.1 \mathrm{~cm}$. RSG-GAS are horizontally modeled by dividing the X and Y-axis distance into several meshs. The axial direction of RSG-GAS is divided into the top of the fuel, the bottom of the fuel and part of the active fuel. The top and the bottom of the fuel are divided into 9 layers, and fuel 8 layers, respectively. An active fuel section with a height of $60 \mathrm{~cm}$ is divided into 12 layers with each layer as high as $5 \mathrm{~cm}$. The modeling of the fuel burn-up class distribution in the RSG-GAS is shown in Figure 3. In those figure, the FEx.y symbol indicates the y-th fuel element (FE) with the fuel burn-up class $\mathrm{x}$. Whereas, CE-x is the fuel control element with the $\mathrm{x}$ class fuel burn-up.

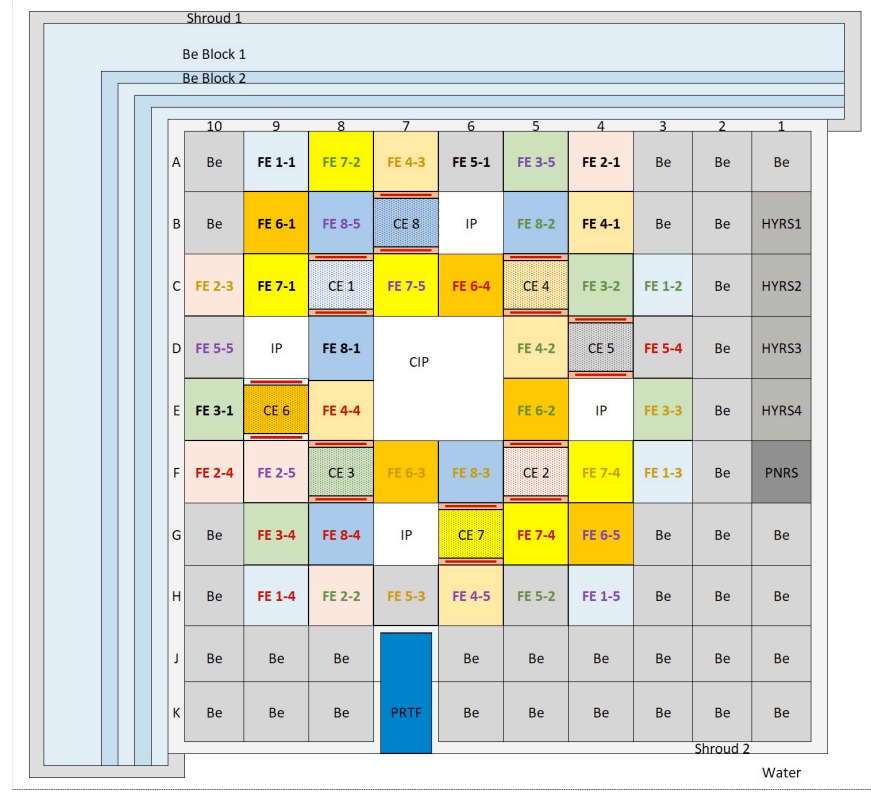

Horizontal (X-Y) Model

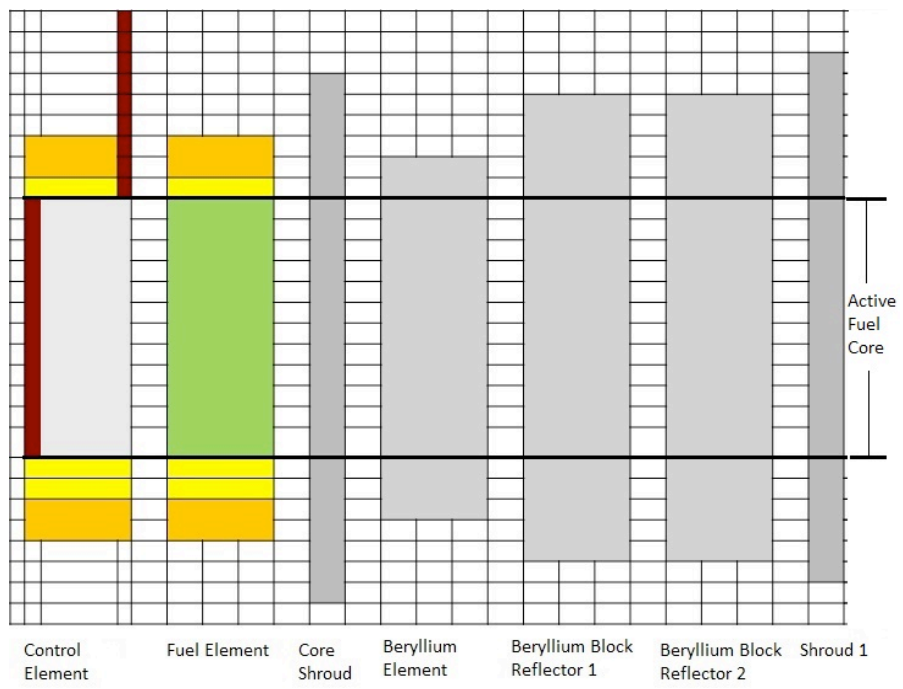

Axial (Z) Model

Figure 3. Horizontal (X-Y) and axial (Z) model of the RSG-GAS core with 5/1 loading pattern of fuel/control element 
- RSG-GAS data operation

As it is known that the standard fuel elements / control fuel elements loading on the RSGGAS core have been changed from the $6 / 1$ and $6 / 2$ loading pattern to the $5 / 1$ loading pattern. The placement position of each fuel for 8 operating cycle operations is shown in Figure 5. The energy generated in each operating cycle is shown in Table 1.

\begin{tabular}{|c|c|c|c|c|c|c|c|c|c|c|c|c|c|c|c|c|c|c|}
\hline out & $\leftarrow$ & B-8 & $\leftarrow$ & $C-7$ & $\leftarrow$ & G-4 & $\leftarrow$ & D-10 & $\leftarrow$ & $\mathrm{H}-6$ & $\leftarrow$ & $A-5$ & $\leftarrow$ & F-9 & $\leftarrow$ & $\mathrm{H}-4$ & $\leftarrow$ & FE1 \\
\hline out & $\leftarrow$ & G-8 & $\leftarrow$ & G-5 & $\leftarrow$ & $C-6$ & $\leftarrow$ & D-3 & $\leftarrow$ & $E-8$ & $\leftarrow$ & G-9 & $\leftarrow$ & $F-10$ & $\leftarrow$ & $\mathrm{H}-9$ & $\leftarrow$ & FE2 \\
\hline out & $\leftarrow$ & $F-6$ & $\leftarrow$ & F-4 & $\leftarrow$ & $\mathrm{F}-7$ & $\leftarrow$ & $\mathrm{H}-7$ & $\leftarrow$ & A-7 & $\leq$ & E-3 & $\leftarrow$ & $C-10$ & $\leftarrow$ & $\mathrm{F}-3$ & $\leftarrow$ & FE3 \\
\hline out & $\leftarrow$ & B-5 & $\leftarrow$ & $A-8$ & $\leftarrow$ & E-5 & $\leftarrow$ & $\mathrm{H}-5$ & $\leftarrow$ & D. 5 & $\leftarrow$ & $C-4$ & $\leftarrow$ & $\mathrm{H}-8$ & $\leftarrow$ & $C-3$ & $\leftarrow$ & FE4 \\
\hline out & $\leftarrow$ & D-8 & $\leftarrow$ & $C-9$ & $\leftarrow$ & B-9 & $\leftarrow$ & $\underline{A-6}$ & $\underline{E}$ & B-4 & $\leftarrow$ & E-10 & $\leftarrow$ & $\mathrm{A}-4$ & $\leftarrow$ & A-9 & $\leftarrow$ & FE5 \\
\hline out & $\leftarrow$ & B-7 & $\leftarrow$ & G-6 & $\leftarrow$ & E-9 & $\leftarrow$ & D-4 & $\leftarrow$ & $C-5$ & $\leftarrow$ & $F-8$ & $\leftarrow$ & $F-5$ & $<$ & $C-8$ & $\leftarrow$ & CF \\
\hline
\end{tabular}

Figure 4. Each fuel class burn-up position with 5/1 loading pattern of standard fuel elements / control fuel element in the RSG-GAS core

Table 1. Full power day of RSG-GAS operation data

\begin{tabular}{cl}
\hline Cycle No. & $\begin{array}{l}\text { Full Power Day } \\
\text { (MWD) }\end{array}$ \\
\hline 78 & 663.58 \\
79 & 636.04 \\
80 & 654.35 \\
81 & 652.14 \\
82 & 652.35 \\
83 & 634.69 \\
84 & 640.28 \\
85 & 642.82 \\
\hline
\end{tabular}

\begin{tabular}{cc}
\hline Cycle No. & $\begin{array}{c}\text { Full Power Day } \\
\text { (MWD) }\end{array}$ \\
\hline 86 & 620.39 \\
87 & 654.00 \\
88 & 630.65 \\
89 & 640.60 \\
90 & 640.06 \\
91 & 640.01 \\
92 & 615.51 \\
93 & 625.05 \\
\hline
\end{tabular}

\section{Calculation Flowchart}

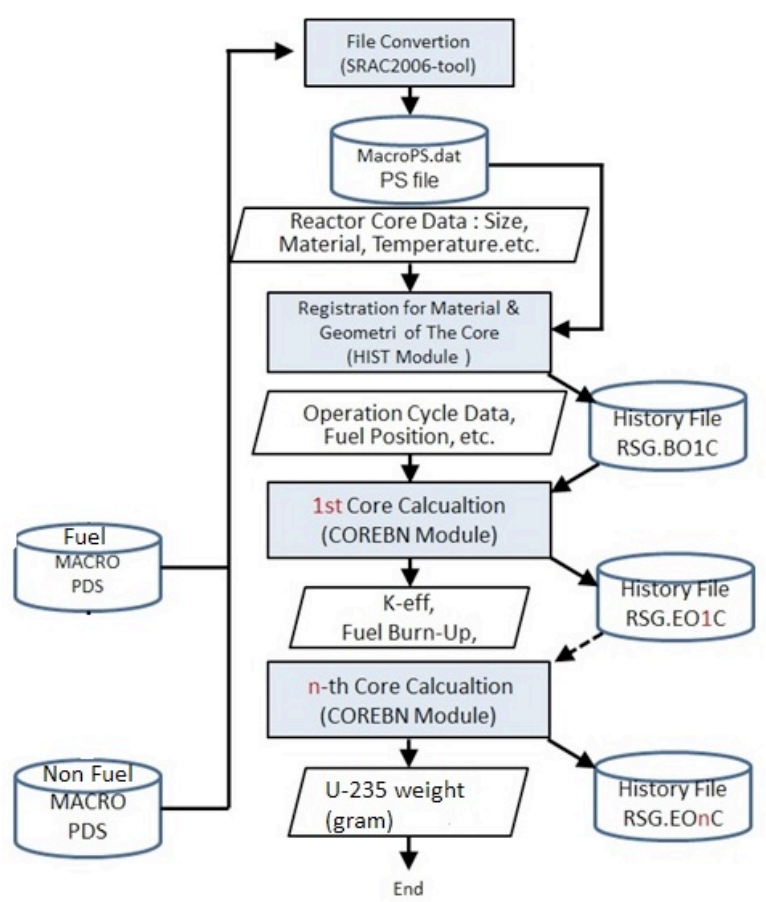

Figure 5. The flowchart of the core calculation using COREBN/HIST 
The flowchart of the core calculation using COREBN/HIST is shown in the Figure 5. After obtaining the above data, then the conversion of all macroscopic cross-section data from PDS file to PS file per. This calculation was performed by using tool that is available in the computer program SRAC2006. Furthermore, to determine the fuel type and geometric shape of RSG-GAS core, then registration to the fuel and nonfuel material in the RSG-GAS core has been performed using HIST module. The required inputs for this calculation are the dimensions of the core, the X$\mathrm{Y}-\mathrm{Z}$ direction mesh distance, and the macroscopic cross-sections of the fuels and nonfuels material. The output generated from this calculation is an initial data of the core material that are stored in the form of a PS file (MacroPs.dat). Calculation of the fuel burn-up distribution on the $n$-th cycle of the core has been done by using of the COREBN/HIST module for the 3-dimentional geometry of the core. The calculation of fuel discharges burn-up on RSG-GAS core performed to all of the operating cycle from 78th to 93th (present) of core. The calculated results by using COREBN/HIST module also compared with the existing data calculated with computer program BATAN-FUEL for the fuel burn-up distribution of RSG-GAS core in the operating cycle number 78th and 88th.

\section{Processing of the Output Data}

The output of COREBN/HIST calculation result data is the weight of U-235 in the gram unit at the beginning and the end of the cycle for each fuel. The weight value of U-235 converted to \% loss of U-235 unit with definition: U-235 weight at beginning of cycle minus U-235 weight at the end of cycle divided by U-235 weight at the beginning cycle, then multiplied by $100 \%$.

\section{RESULTS AND DISCUSSION}

The calculation results of the fuel burn-up at the $78^{\text {th }} \& 88^{\text {th }}$ cycle operation of the RSG-GAS core using SRAC2006 are shown at the Figure 6 and 7, respectively. In the $78^{\text {th }}$ and $88^{\text {th }}$ operating cycle, RSG-GAS core uses a 5 standard fuel elements and 1 control element-loading pattern. Hence, there are 6 fuels in each class of fuel burn-up. It can be said that at the BOC at each operating cycle, there are each class burn-up of fuel (every 6 fuels) that have been extending in the core for $0,1,2,3,4$, 5,6 and 7 cycle operation, respectively. While in the EOC each group of fuel is extended in the core for $1,2,3,4,5,6,7$ and 8 operation cycles, respectively.

From both figures, it can be seen that there are almost the same fuel burn-up value for each position of fuel loading. It can also be seen that distribution of fuel burn-up is fairly even, and a consistent burn-up change in each class of fuel burn-up. Therefore, from the investigation and from calculation of fuel burn-up, it can be concluded that there is no fuel misplacement.

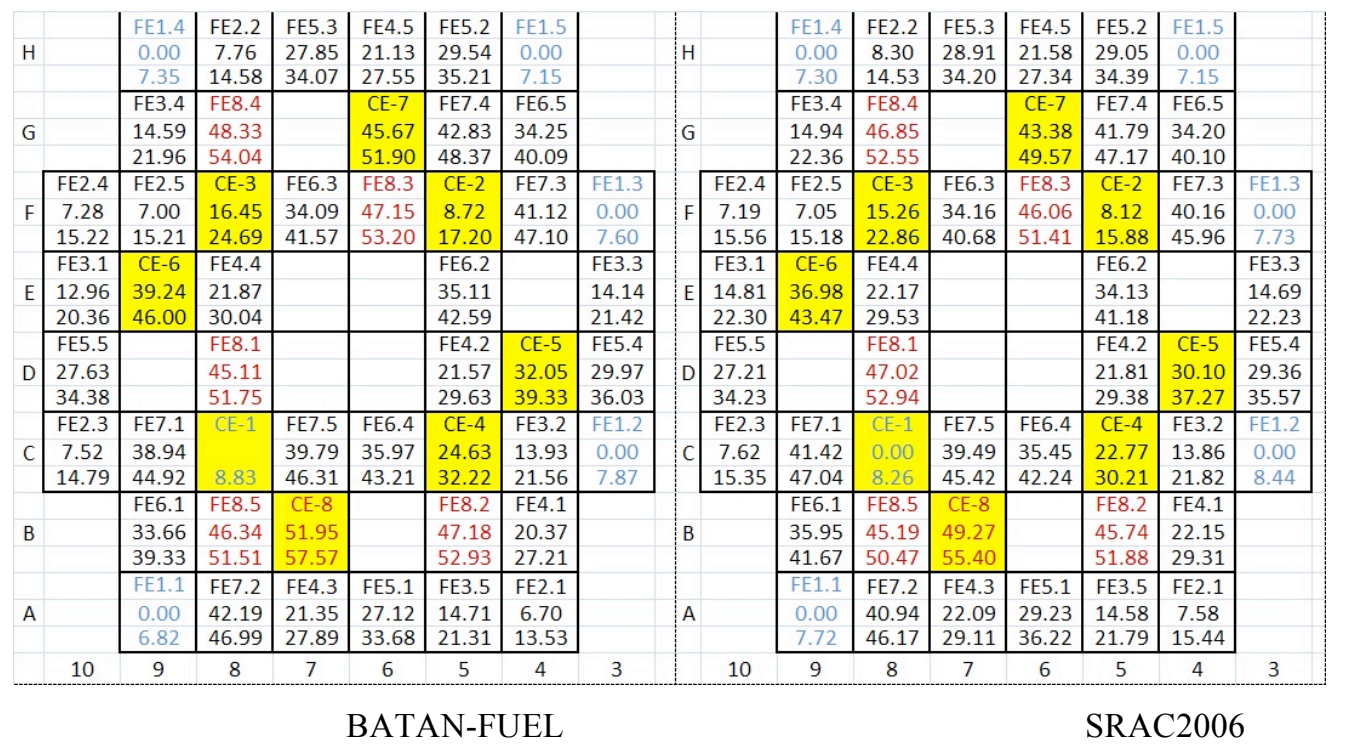

Figure 6. Calculated results of fuel burn-up at the 78th core using BATAN-FUEL and SRAC2006 codes 
The difference between the largest and the smallest fuel burn-up shows an increasing value with increasing of the class of fuel burn-up. Each burn-up class of 1, 2, 3, 4, 5, 6, 7 and 8 for 78th / 88th cycle operation core shows burn-up increments (in units \% of U-235) of 1.30/1.05, 1.36/1.30, $1.07 / 1.07,2.88 / 2.69,3.07 / 2.82,3.37 / 3.38,4.15 / 3.75,4.93 / 4.57$. The highest fuel burn-up values occur in the control fuel element for each burn-up class. As mentioned earlier that at each edge of control element replaced 3 fuel plates with the blade of the control absorber. In the calculation of RSG-GAS core fuel burn-up distribution, the modeling is done using the assumption that all absorbent materials are fully up (substituted with water). It causes a lot of fast neutrons moderated into thermal neutron. Therefore, fuel burn-up of control fuel elements produced higher than standard fuel elements. Due to the accumulation of different fuel burn-up in each cycle for 7 cycles before, the difference between largest and smallest fuel burn-up at the 8th fuel burn-up class is large enough which is more than $4 \%$ of U-235.

Meanwhile the smallest fuel burn-up values at each level of the fuel class burn-up are shown by FE1.5, FE2.2, FE3.5, FE4.5, FE5.5, FE6.5, FE7.5 and FE8.5 fuels. In the previous seven cycles, the FE8.5 fuel occupied 6 positions where the smallest fuel burn-up was generated, ie, at FE1.5, FE3.5, FE.4.5, FE5.5 FE6.5 and FE7.5 fuel positions. The condition of the position of the smallest fuel burnup is also one of the causes of the large difference between the largest and smallest fuel burn-up.

In terms of standard fuel elements, the differences between the largest and the smallest fuel burn-up in the same class of fuel burn-up represent the highest numbers of $2.12 \%$ of U-235 and $2.46 \%$ of U-235 for the $88^{\text {th }}$ and $78^{\text {th }}$ operating cycles, respectively.

\begin{tabular}{|c|c|c|c|c|c|c|c|c|c|c|c|c|c|c|c|c|c|}
\hline & & FE1.4 & FE2.2 & FE5.3 & FE4.5 & FE5.2 & FE1.5 & & & & FE1.4 & FE2.2 & FE5.3 & FE4.5 & FE5.2 & FE1.5 & \\
\hline \multirow[t]{3}{*}{$\mathrm{H}$} & & 0.00 & 7.38 & 27.35 & 20.85 & 28.97 & 0.00 & & $\mathrm{H}$ & & 0.00 & 7.96 & 28.67 & 21.38 & 28.82 & 0.00 & \\
\hline & & 6.92 & 13.78 & 33.39 & 27.13 & 34.43 & 6.76 & & & & 6.92 & 13.89 & 33.71 & 26.87 & 33.91 & 6.79 & \\
\hline & & FE3.4 & FE8.4 & & CE-7 & FE7.4 & FE6.5 & & & & FE3.4 & FE8.4 & & CE-7 & FE7.4 & FE6.5 & \\
\hline \multirow[t]{3}{*}{ G } & & 14.37 & 47.85 & & 45.34 & 42.30 & 33.50 & & G & & 14.78 & 47.12 & & 43.01 & 41.81 & 33.77 & \\
\hline & & 21.38 & 53.32 & & 51.31 & 47.60 & 39.08 & & & & 21.83 & 52.52 & & 48.93 & 46.93 & 39.40 & \\
\hline & FE2.4 & FE2.5 & CE-3 & FE6.3 & FE8.3 & CE-2 & FE7.3 & FE1.3 & & FE2.4 & FE2.5 & CE-3 & FE6.3 & FE8.3 & CE-2 & FE7.3 & FE1.3 \\
\hline \multirow[t]{3}{*}{$\mathrm{F}$} & 6.92 & 6.70 & 16.21 & 33.39 & 46.56 & 8.31 & 40.64 & 0.00 & $F$ & 6.90 & 6.75 & 15.08 & 33.79 & 45.88 & 7.79 & 40.22 & 0.00 \\
\hline & 14.43 & 14.52 & 24.02 & 40.51 & 52.35 & 16.35 & 46.34 & 7.18 & & 14.85 & 14.48 & 22.32 & 40.00 & 50.99 & 15.19 & 45.74 & 7.34 \\
\hline & FE3.1 & CE-6 & FE4.4 & & & FE6.2 & & FE3.3 & & FE3.1 & CE-6 & FE4.4 & & & FE6.2 & & FE3.3 \\
\hline \multirow[t]{3}{*}{$\mathrm{E}$} & 12.83 & 38.64 & 21.48 & & & 34.43 & & 13.98 & $E$ & 14.65 & 36.58 & 21.99 & & & 33.99 & & 14.56 \\
\hline & 19.87 & 45.13 & 29.25 & & & 41.56 & & 20.90 & & 21.76 & 42.78 & 28.99 & & & 40.72 & & 21.73 \\
\hline & FE5.5 & & FE8.1 & & & FE4.2 & CE-5 & FE5.4 & & FE5.5 & & FE8.1 & & & FE4.2 & CE-5 & FE5.4 \\
\hline \multirow[t]{3}{*}{ D } & 27.13 & & 44.42 & & & 21.18 & 31.61 & 29.38 & $\mathrm{D}$ & 27.02 & & 46.78 & & & 21.55 & 29.67 & 29.15 \\
\hline & 33.56 & & 50.75 & & & 28.83 & 38.56 & 35.14 & & 33.69 & & 52.42 & & & 28.75 & 36.51 & 35.06 \\
\hline & FE2.3 & FE7.1 & CE-1 & FE7.5 & FE6.4 & CE-4 & FE3.2 & FE1.2 & & FE2.3 & FE7.1 & CE-1 & FE7.5 & FE6.4 & CE-4 & FE3.2 & FE1.2 \\
\hline \multirow[t]{3}{*}{ C } & 7.15 & 38.58 & 0.00 & 39.34 & 35.32 & 24.21 & 13.78 & 0.00 & $c$ & 7.30 & 41.24 & 0.00 & 39.56 & 35.14 & 22.47 & 13.81 & 0.00 \\
\hline & 14.05 & 44.29 & 8.36 & 45.56 & 42.24 & 31.42 & 21.04 & 7.43 & & 14.65 & 46.58 & 7.84 & 45.18 & 41.61 & 29.56 & 21.37 & 8.01 \\
\hline & & FE6.1 & FE8.5 & CE-8 & & FE8.2 & FE4.1 & & & & FE6.1 & FE8.5 & CE-8 & & FE8.2 & FE4.1 & \\
\hline \multirow[t]{3}{*}{ B } & & 32.91 & 45.72 & 51.50 & & 46.55 & 20.00 & & B & & 35.57 & 45.40 & 49.13 & & 46.02 & 21.91 & \\
\hline & & 38.31 & 50.67 & 56.90 & & 52.04 & 26.49 & & & & 41.02 & 50.40 & 54.96 & & 51.83 & 28.73 & \\
\hline & & FE1.1 & FE7.2 & FE4.3 & FE5.1 & FE3.5 & FE2.1 & & & & FE1.1 & FE7.2 & FE4.3 & FE5.1 & FE3.5 & FE2.1 & \\
\hline \multirow[t]{3}{*}{ A } & & 0.00 & 41.77 & 21.00 & 26.64 & 14.43 & 6.42 & & A & & 0.00 & 40.95 & 21.87 & 28.84 & 14.00 & 7.26 & \\
\hline & & 6.46 & 46.37 & 27.23 & 32.88 & 20.69 & 12.91 & & & & 7.30 & 45.91 & 28.55 & 35.50 & 21.25 & 14.75 & \\
\hline & 10 & 9 & 8 & 7 & 6 & 5 & 4 & 3 & & 10 & 9 & 8 & 7 & 6 & 5 & 4 & 3 \\
\hline
\end{tabular}

Figure 7. Calculation result of fuel burn-up at the 88th core using BATAN-FUEL and SRAC2006

Table 2. Differences fuel control element burn-up value due to the absorbent material position

\begin{tabular}{lcccccccc}
\hline \multirow{2}{*}{ Absorber Position } & \multicolumn{7}{c}{ Control Fuel Element Burn-Up at the EOC } \\
\cline { 2 - 9 } & CE-1 & CE-2 & CE-3 & CE-4 & CE-5 & CE-6 & CE-7 & CE-8 \\
\hline FullyUp Bank & 7.84 & 15.19 & 22.32 & 29.56 & 36.51 & 42.78 & 48.93 & 54.96 \\
Critically Bank & 7.66 & 15.12 & 22.27 & 29.42 & 36.35 & 42.66 & 48.83 & 54.72 \\
Difference & 0.18 & 0.07 & 0.05 & 0.14 & 0.17 & 0.12 & 0.10 & 0.24 \\
\hline
\end{tabular}


As shown in Table 2, since the position of the absorbers in the fuel control elements were considered, it is an approximate of the actual reactor operation condition, then the difference in the fuel burn-up for 8 cycles is total $1.07 \%$ of U-235 or an average of $0.13 \%$ of U-235 lower per cycle. Therefore, the difference between the smallest and largest of fuel burn-up will slightly decrease to about $3.80 \%$ compare with the calculation performed without absorbent material in the core. Readjusting the fuel placement pattern may still reduce the difference of the fuel discharge burn-up.

From Figure 6 and 7, it can be seen also that during one operation cycle, the largest change in fuel burn-up is shown in FE2.4 fuel at the F-10 position of $8.36 \%$ of U-235 and $7.96 \%$ of U-235 in cycle operation $78^{\text {th }}$ and $88^{\text {th }}$, respectively. It shows that in that grid position it has the biggest reaction rate. While the smallest change occurred in FE7.2 fuel position A-8, i.e 4.96\% of U-235 and $5.22 \%$ of U-235, respectively in the 78th and 88th operating cycles. This is due to the FE7.2 fuel has reached a high burn-up or has passed the previous 7 cycles of operation, resulting in lower contain in U-235 caused by fission reaction. In addition, the FE7.2 fuel position is on the edge of core where the neutron flux is lower. The smaller U-235 content, and position in the core resulting in the smallest change burn-up in the one cycle operation. It is also known that the fuel discharge burn-up, which has reached for the 8 operating cycles, shows a value that is below the limit determined by the regulatory body $(<60.00 \%$ of $U-235)$

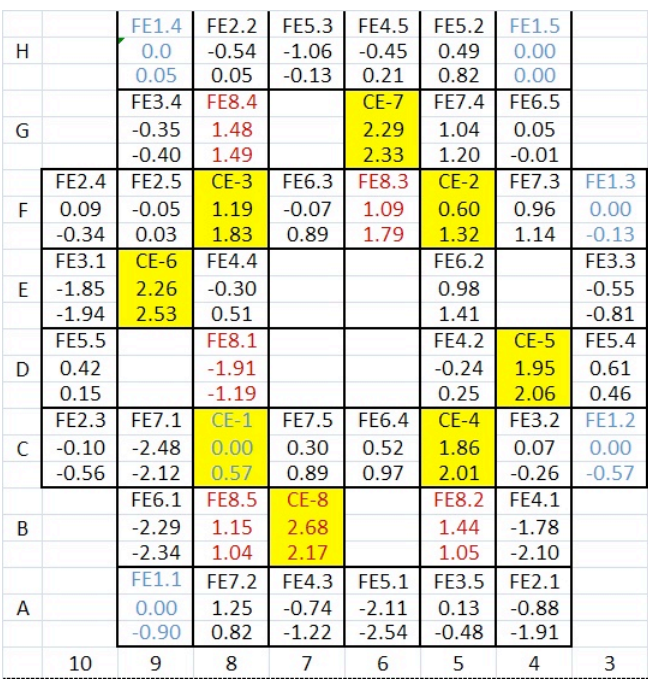

(1)-(2)

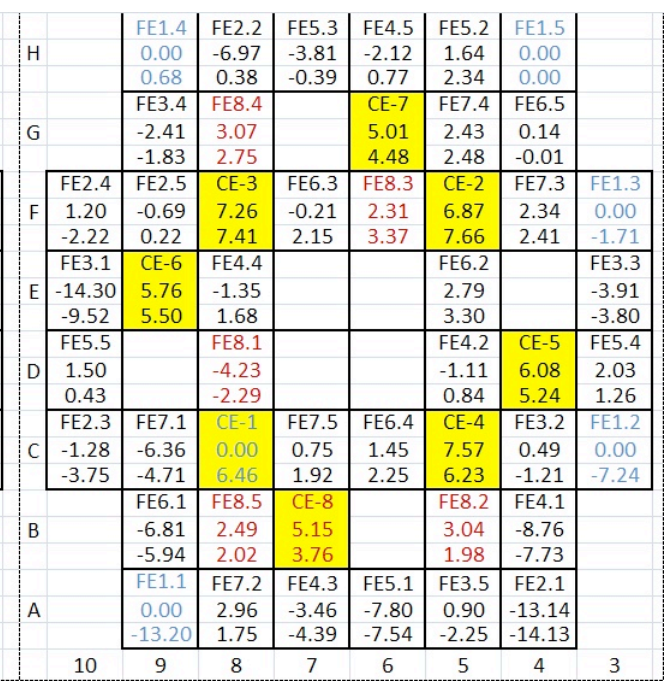

$(\%)$

Figure 8. Calculated fuel burn-up differences at the $78^{\text {th }}$ core using between BATAN-FUEL and SRAC06

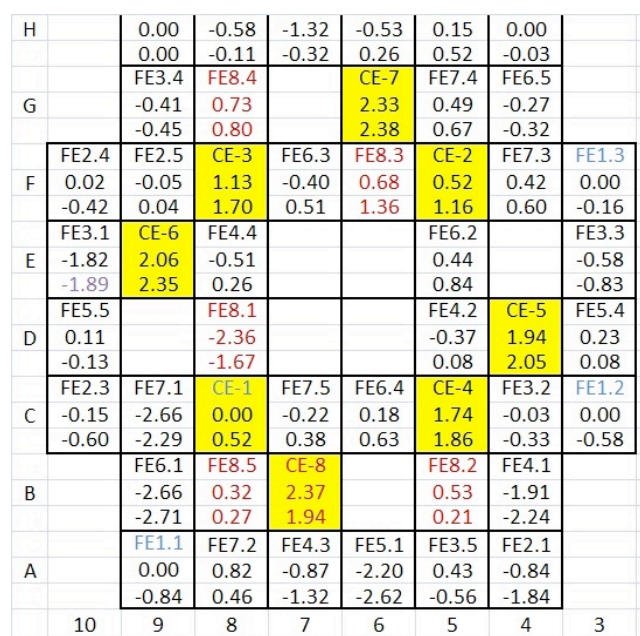

(1)-(2)

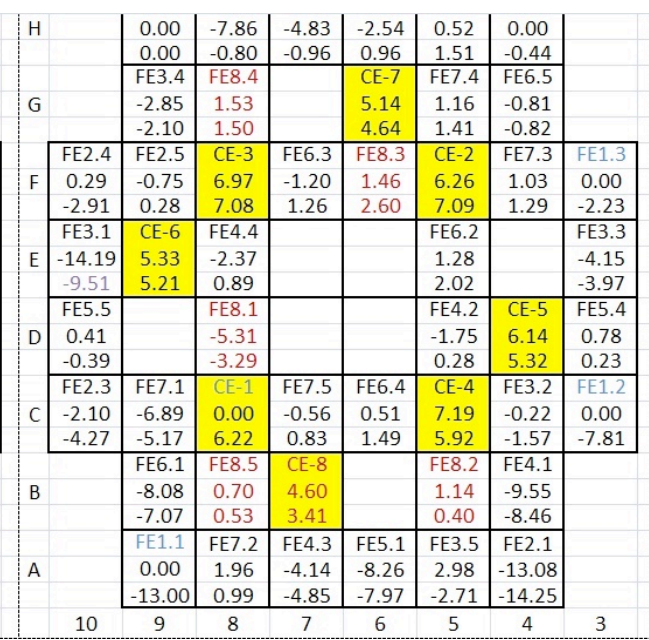

$(\%)$

Figure 9. Calculated fuel burn-up differences at the $88^{\text {th }}$ core using between BATAN-FUEL and SRAC06 
Figure 8 and 9 show the calculated fuel burn-up differences respectively at the $78^{\text {th }} \& 88^{\text {th }}$ operation cycle of the core between using BATAN-FUEL and SRAC2006 codes. From these two figures it can be seen that the biggest difference occurs in the FE2.1 of position A-4, which is about $1.91 \%$ of U-235 \& $-1.84 \%$ of U-235 or about $-14.13 \% \&-13.08 \%$, respectively for $78^{\text {th }}$ and $88^{\text {th }}$ operating cycles at the EOC. Meanwhile the smallest difference of $0 \%$ of U-235 is shown on FE1.5 and FE1.4 fuels, in each $78^{\text {th }}$ and $88^{\text {th }}$ operating cycle. For fuel that has achieved discharges burn-up, FE8.1, FE8.2, FE8.3, FE8.4, FE8.5 and CE-8, shows the differences in calculated results about $-1.19 \%$ of U-235 (-2.29\%), 1.05\% of U-235 (1.98\%), 1.79\% of U-235 (3.37\%), 1.49\% of U-235 (2.75\%), $1.04 \%$ of U-235 $(2.02 \%)$, and $-2.17 \%$ of U-235 $(3.76 \%)$ in the 78 th operating cycle. Whereas on the 88th core operating cycle, the differences are $-1.67 \%$ of U-235 $(-3.29 \%), 0.53 \%$ of U-235 $(0.4 \%)$, $0.68 \%$ of U-235 (2.6\%), $0.80 \%$ of U-235 (1.50\%), $0.27 \%$ of U-235 (0.53\%) and $1.94 \%$ U-235 $(3.41 \%)$. Therefore, it can be said that the calculated results of discharge burn-up fuel of RSG-GAS core are in good agreement when it is performed using the two computational program BATAN-FUEL and SRAC2006 module of COREBN/HIST.
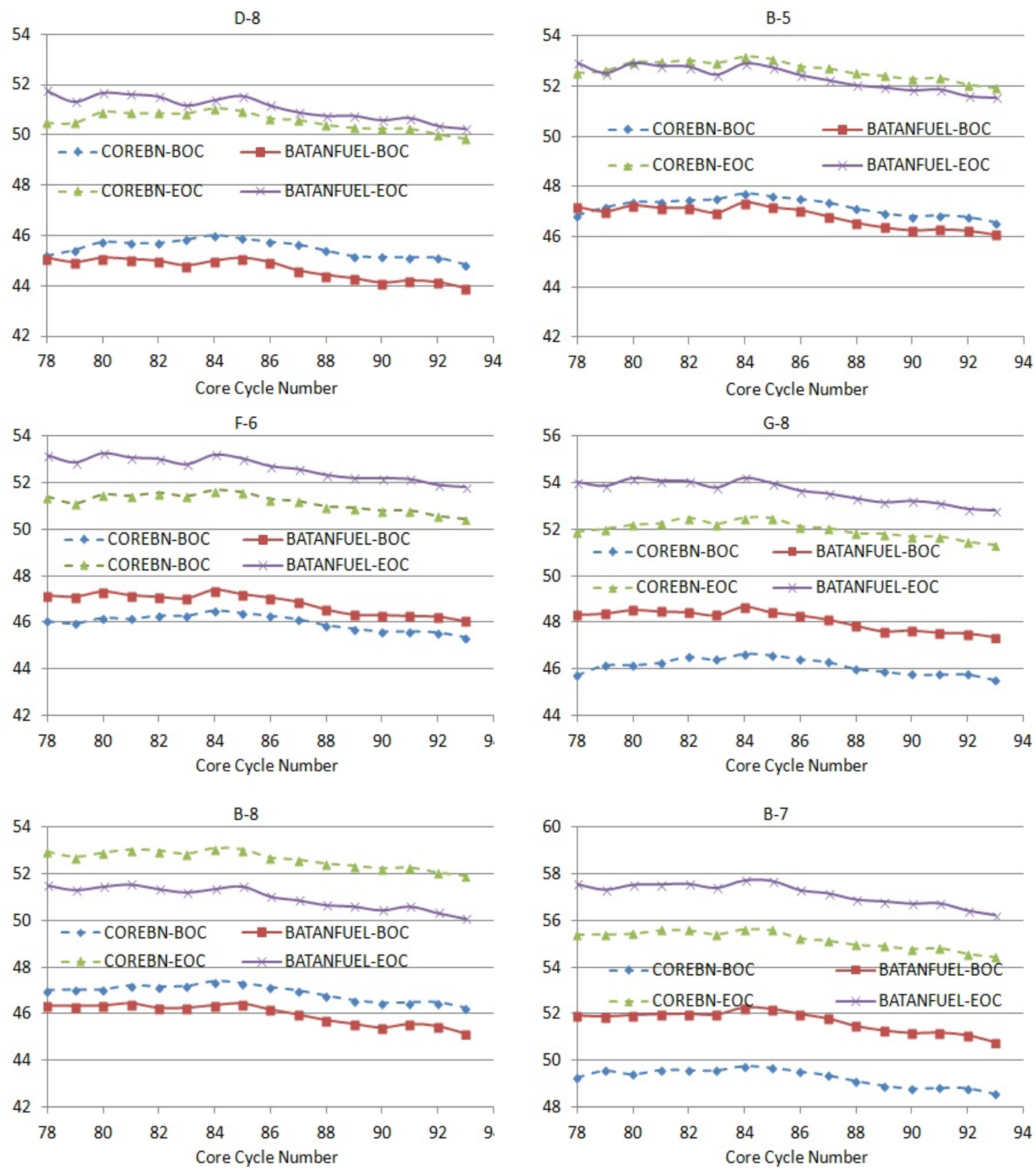

Figure 10. Value of discharge burn-up calculated using COREBN/HIST and BATAN-FUEL 
Figure 10 shows the difference in the fuel discharge burn-up of each position on the RSGGAS at the $78^{\text {th }}$ to $94^{\text {th }}$ operation cycle calculated using BATAN-FUEL computer program and the COREBN/HIST module of SRAC2006. From the figure, it can be seen that the value of fuel discharge burn-up of RSG-GAS core calculation using SRAC2006 module of COREBN/HIST shows conformity with the operating data calculated using BATAN-FUEL. In general, comparison of calculated result using COREBN/HITS and BATAN-FUEL shows almost equal values at position D-8 and B-5. At position B-8 it shows a slightly larger fuel discharge burn-up. While in the position of $\mathrm{F}-6, \mathrm{G}-8$ and $\mathrm{B}-7$ show smaller value.

In the fuel at position D-8, B-5, F-6, G-8, B-8 and B-7, the differences in the calculations between BATAN-FUEL and COREBN/HIST at BOC / EOC in unit \% of U- 235 are $-0.82 / 0.54$, $0.39 /-0.31,0.81 / 1.49,1.96 / 1.61,-0.93 /-1.63$, and 2.43/1.98 respectively. At BOC the result of calculation using BATAN-FUEL is lower than COREBN/HIST. The difference of calculation result is due to the difference of computer program, also the input model used, that is 2-dimensional and 3-dimensional geometry form for each calculation using BATAN-FUEL and COREBN / HIST, respectively.

The average change of the fuel burn-up in one cycle at the position of D-8, B-5, F-6, G-8, B8 and B-7 calculated with BATAN-FUEL / COREBN/HIST in unit \% of U- 235 are 6.42/5.06, $5.55 / 5.47,5.84 / 5.16,5.52 / 5.87,5.01 / 5.71$, and 5.46/5.91 respectively. It shows the differences of $1.35,0.08,0.68,-0.35,-0.70$, and -0.45 in units $\%$ of U-235. Therefore, it can be said that calculated results using BATAN-FUEL and COREBN/HIST are in a good agreement. Both computer program BATAN-FUEL and COREBN/HIST calculation result show that the fuel discharge burn-up is still under allowable values by regulatory body.

Fluctuations in the value differences of the largest and smallest fuel discharge burn-up in the D-8, B-5, F-6, G-8, B-8 and B-7 positions for 15 operating cycles (78th to 93rd core), respectively using BATAN-FUEL / COREBN/HSIT module of SRAC2006 in units \% of U-235 are 1.52/1.22, $1.38 / 1.27,1.45 / 1.24,1.41 / 1.18,1.45 / 1.19$, and 1.52/1.21. In addition, the average fluctuation value is found to be 1.46/1.22 (\% of U-235). Therefore, it can be said that the implementation of in-core fuel management on the RSG-GAS has shown a very good performance. It can be seen from the value of fuel discharge burn-up that is steady and consistent in every cycle of operation.

From the analysis of the above calculation results, it can be said that the implementation of in-core fuel management RSG-GAS has been implemented with design. Therefore, the value of burning fuel fraction generated by RSG-GAS core fuel has been verified not exceeding the allowable limit. Maximum fuel discharge burn-up (57.73\% of U-235) is still under permissible value determined by the regulatory body $(<60 \%$ of U-235). Comparison of calculation results between COREBN/HIST and BATAN-FUEL computer programs indicates conformity to the fuel burn-up discharge values produced by RSG-GAS core. Maximum differences value between two computer codes was about $2.12 \%$ of U-235 (3.80\%) that is fuel at the B-7 position.

\section{CONCLUSION}

Discharge fuel burn-up of RSG-GAS is verified under permissible value determined by regulatory body ( $<60.00 \%$ of U-235). The pattern of placement and loading of fuel on RSG-GAS core for the last 10 years (up to the $93^{\text {rd }}$ operating cycle) is in accordance with the design. Fuel discharge burn-up of RSG-GAS shows almost the same value for each of the operation cycle. Therefore, it can be concluded that the RSG-GAS core operation over the last ten years has shown good in-core fuel management performance, in accordance with the design. Calculated results using BATAN-FUEL shows a good agreement with small differences (maximum about $2.12 \%$ of U-235 (3.80\%)) to the SRAC06 module COREBN/HIST. BATAN-FUEL has been comformed well enough with COREBN/HIST. 


\section{ACKNOWLEDGEMENT}

This research has been completed under financial support from the Indonesian government budget of DIPA2017-PTKRN, PRSG-BATAN and IAEA under contract no. T3-TM-55821; EVT1700355, and authors would like to thank to the Head of PTKRN, Head of PRSG and IAEA for the facility and senior researchers for support and advice.

\section{REFERENCES}

1. Surbakti T., Purwadi. Reactivity characteristic of RSG-GAS working core for 30 years operation. J. Penelit. Fis. dan Apl. 2017. 7(1):13-26.

2. Díez C.J., Buss O., Hoefer A., Porsch D., Cabellos O. Comparison of nuclear data uncertainty propagation methodologies for PWR burn-up simulations. Ann. Nucl. Energy. 2015. 77:101-14.

3. Susilo J., Pane J.S. Fuel burn-up distribution and transuranic nuclide contents produced at the first cycle operation of AP1000. Tri Dasa Mega. 2015. 18(2):101-11.

4. Wan C., Cao L., Wu H., Shen W. Nuclear-data uncertainty propagations in burnup calculation for the PWR assembly. Ann. Nucl. Energy. 2017. 100:20-31.

5. Cabellos O., Castro E., Ahnert C., Holgado C. Propagation of nuclear data uncertainties for PWR core analysis. Nucl. Eng. Technol. 2014. 46(3):299-312.

6. Margulis M., Gilad E. Monte Carlo and nodal neutron physics calculations of the IAEA MTR benchmark using Serpent/DYN3D code system. Prog. Nucl. Energy. 2016. 88:118-33.

7. Sembiring T.M., Liem P.H. Development and verification of fuel burn-up calculation model in a reduced reactor geometry. Ann. Nucl. Energy. 2008. 35(2):167-74.

8. Ginting A.B., Liem P.H. Absolute burnup measurement of LEU silicide fuel plate irradiated in the RSG GAS multipurpose reactor by destructive radiochemical technique. Ann. Nucl. Energy. 2015. 85:613-20.

9. Nampira Y., Ismarwanti S., Sufmawan A., Mustofa K. Utilization of gamma spectrometry for observation of distribution of cleavage in nuclear fuel elements post irradiation. Urania. 2014. 20(2):84-91.

10. Boybul, Yanlinastuti, Ginting A.B. Analysis of cesium and uranium content inirradiated U3Si2-Al fuel. Urania. 2017. 23(2):107-16.

11. Pinem S., Liem P.H., Sembiring T.M., Surbakti T. Fuel element burn-up measurements for the equilibrium LEU silicide RSG GAS (MPR-30) core under a new fuel management strategy. Ann. Nucl. Energy. 2016. 98:211-7.

12. Laporan Operasi Reaktor RSG-GAS Teras 78 - 94, No.Ident:RSG.OR.XX.04.44.12-17. Tangerang Selatan Indonesia : Center for Multipurpose Research Reactor, National Atomic Energy Agency; 2012-2017. 